\title{
O que é virtual?
}

LÉVY, Pierre. O que é virtual? Trad. Paulo Neves. São Paulo, Ed. 34, 1996. 157p.
Trata-se de um livro atual, traduzido de primeira edição francesa datada de 1995, na qual o autor reflete sobre um tema contemporâneo que afeta a cultura moderna - a virtualização.

No esforço de nos fazer aprender, pensar e compreender o tema em toda a sua amplitude, o autor inicia pela definição e estabelecimento de características da virtualidade, enfatizando, sobremaneira, as alterações que ela traz nas concepções de espaço (desterritorialização) e de tempo (desprendimento do aqui e agora). O virtual, diz ele, usa novos espaços e novas velocidades, sempre problematizando e reinventando 0 mundo. Outro caráter que confere à virtualidade é o de sua passagem do interior ao exterior e do exterior ao interior (efeito Mochius). No virtual, explica ele, os limites de espaço não são mais dados e há um compartilhamento de tudo, tornando difícil distinguir o que é público do que é privado, o que é próprio do que é comum, o que é subjetivo do que é objetivo.

A presença destas características no virtual é, posteriormente, aplicada ao corpo, à produção do texto e à economia.

Pontuando nosso interesse pela obra, salientamos que, quando o autor aborda a virtualização da economia, colocaa dependente de dois bens primordiais e particulares: as informações e os conhecimentos. Considera-os primordiais porque se constituem nos elementos mais importantes para a produção de riquezas na atualidade; e particulares porque se diferem de outros bens pelas suas características de serem partilháveis, uma vez que cedê-los não faz com que se percam e consumi-los não os destrói. Além disso, quando submetidos à virtualização, estes dois bens se desterritorializam e se desprendem do aqui e agora, colocando-se em um espaço comum para todos, com possibilidades de apropriações não exclusivas. Quando os atualizamos (trazemos para o real), ou seja, utilizamos para a solução de um problema, realizamos um processo de interpretação, de ligação a outras informações e conhecimentos e, com isso, promovemos um ato de criação e invenção, tão importante para o gênero humano.

Longe de ligar a virtualização a uma ameaça da tecnologia atual ao homem, Lévy faz questão de humanizá-la, mostrando que três dos processos que fizeram emergir a espécie humana - a linguagem, a técnica e as instituições sociais complexas - estão imbuídos de um movimento que encerra um potencial, um "devir outro", que caracteriza o virtual. Enfatiza que o uso da virtualização, cada vez mais presente no nosso cotidiano, amplia as potencialidades humanas, criando, inclusive, um novo modo de aprender e de pensar.

Mesmo que ainda estejamos receosos de assumir a virtualização como um processo irreversível, por não compreendêla ou não saber de suas conseqüências, o autor mostra que a passagem para o virtual é a força e a velocidade pelas quais se direciona a cultura atual. Antes de temer que ela torne as pessoas desprendidas de seus próprios saberes, de sua identidade, de seus empregos, de sua profissão e de seu país, precisamos acompanhar "...as tendências mais positivas da evolução em curso [criando] um projeto de civilização centrado sobre os coletivos pensantes." Finalizando, Lévy nos convida a enveredar por esta nova aventura que são os caminhos do virtual, uma vez que - e terminamos o livro convencidos disso ele é o inevitável. 